\title{
Study on Environmental Impact Assessment of Technological Transformation Project of X Corporation
}

\author{
Dianwei Qi ${ }^{1} \&$ Xin Zhang ${ }^{1}$ \\ ${ }^{1}$ Chang Chun University of Science and Technology, Changchun, China \\ Correspondence: Dianwei Qi, Chang Chun University of Science and Technology, Changchun, 130022, China. \\ Tel: 86-151-0446-3172. E-Mail: qidianwei1111@126.com
}

Received: April 2, 2013 Accepted: May 29, 2013 Online Published: June 29, 2013

doi:10.5539/ass.v9n9p205 URL: http://dx.doi.org/10.5539/ass.v9n9p205

\begin{abstract}
China is the world first country to produce cement. It is necessary for concrete construction project to implement environmental impact assessment according to national legal requirements. Applying the theory of the environmental impact assessment and environmental impact laws and regulations ,based on engineering analysis and environmental status investigation and evaluation, the paper studies on environmental impact assessment about technological transformation project of X Corporation and analysis and forecast the extent and scope of the environmental impact on the area where the technological transformation project is located, to put forward possible preventive measures and mitigation measures in order to minimize the adverse impact which provides the scientific basis for environmental management department decision-making. The ultimate goal is to implement sustainable development strategies and comprehensive utilization of resources.
\end{abstract}

Keywords: environmental impact assessment, technological transformation project, clean production

\section{Introduction}

The environmental impact assessment is an important part of project evaluation system that refers to environmental impact analysis, forecasting and assessment the likely environmental impact of the planned and implementation of construction projects, and put forward policies and measures to prevent or mitigate adverse environmental impacts.

In 1969, the United States first proposed the concept of environmental impact assessment and formulated "National Environmental Policy Act". Subsequently, Japan, Canada, UK, Sweden, Macao, Japan and Asia, France, also began to practise. Since the late 1970s, China implemented environmental impact assessment systems which enacted "Environmental Protection Law" in 1979 that required new construction, renovation and expansion project must be made an environmental impact report. In 2002, China promulgated the "People's Republic Environmental Impact Assessment Law" which stipulated that the environmental impact assessment to forecast and assess environmental impact of implementation of the planning and construction projects, in order to prevent or mitigate adverse environmental impacts and bring forward policies and measures.

\subsection{Project Overview}

X corporation was founded in 2005, and in that year and the next year was in operation for two 4000t / d new dry process cement clinker production line, and in 2006 and 2007, constructed pure low temperature waste heat power station of $2 \times 6.5 \mathrm{MW}$. After the power station put into operation, because the production line imported analyser using CBX distribution raw ingredients online from the United States , and rotary kiln using coal burner of $5000 \mathrm{t} / \mathrm{d}$ and the transformation of the kiln end system, the rotary kiln production increased, resulting in much waste heat from exhaust gas has not been fully utilized. Considering the status quo of the existing new dry process cement kiln of $2 \times 4000 \mathrm{t} / \mathrm{d}$ and pure low temperature waste heat power generation of $2 \times 6.5 \mathrm{MW}$ supported, X corporation plans to make further use of waste heat of the head and the end of kiln of the cement clinker production line, and plans to invest 27.64 million Yuan to implement technical reconstruction and build the new set of waste heat generator of $6.5 \mathrm{MW}$ to implement technological transformation of the waste heat power generation project of $6.5 \mathrm{MW}$. Annual design capacity of the project is 51.48 million electricity $\mathrm{kWh}$, and supply the cement plant electricity $47,876,000 \mathrm{kWh}$. 


\subsection{The Original Pollutions Project-Related}

This project is technological transformation project of $6.5 \mathrm{MW}$ of the pure low temperature waste heat power generation, so the main environmental issues are the original pollutions related to the project and the existing environmental pollution of the waste heat power generation system.

After the second phase project expansion, the combination of cement kiln waste heat resources, $\mathrm{X}$ corporation will use the waste heat power generation technology production line and use installed program of two sets of 6.5MW gas turbine waste heat boiler +2 sets of kiln waste heat boiler units. The average power output will be $12 \mathrm{MW}$, and annual generation capacity will be 84 million $\mathrm{kWh}$, annual power supply 77.28 million $\mathrm{kWh}$.

\section{1) Exhaust}

The pure low temperature waste heat power generation technology is to change exhaust gas of the cement kiln and kiln clinker production line into heat through the waste heat boiler and then return them to the cement production system through the kiln emissions, which is just a process of energy conversion which does not produce gas pollutants itself. The pollution emission sources of the heat power station-related emissions are waste from cement production line and kiln production lines. According to the acceptance of environmental monitoring results of the first phase completion project and actual work of the second phase, at present, the whole station kiln exhaust particles (less than $30 \mathrm{mg} / \mathrm{Nm} 3$ ) and $\mathrm{SO} 2$ emission concentration (lower than the original emission standards, near the detection limit) and the emission volume accord with national emission standards.

\section{2) Waste water}

The main waste water of the existing waste water heat power station is cooling clean water, emissions of $634 \mathrm{~m} 3$ / d that is $196,540 \mathrm{~m} 3$ / a. The concentration of major pollutants: $\mathrm{pH}$ value is $7.5, \mathrm{SS}$ is $30 \mathrm{mg} / \mathrm{L}$, and COD is $25 \mathrm{mg} / \mathrm{L}$. The quality of the water is clean as first-line, second-line humidifier water after filtration treatment without emissions. The existing sewage treatment plant will be designed to handle the size of $15 \mathrm{~m} 3 / \mathrm{h}$ that is $360 \mathrm{~m} 3 / \mathrm{d}$ to meet the treatment needs. After the above treatment through sewage treatment system, the quality of water meet the reuse water quality requirements as humidifier water. Therefore, the whole plant production wastewater and domestic sewage will achieve zero emissions.

\section{3) Solid waste}

The waste heat power station does not produce industrial solid waste itself, only using ashes of $7.4 \mathrm{t} / \mathrm{h}$ from the process of the heat transformation of the exhaust of kiln head and end which are back for some of clinker production, designed considering to use spiral conveyors by which respectively the nearest ash is sent clinker production system back without more than rows.

\section{4) Noise source}

The main noise source of the waste heat power station is noise from the induced draft fan, blowers, turbines and pumps. The measured noise is below $90 \mathrm{~dB}(\mathrm{~A})$.

\subsection{The Main Environmental Protection Objectives}

The transformation does not increase exhaust pollution emissions, resulting in a small amount of wastewater and sewage which can be treated to reuse without more than rows. The sound level of the new increased noise source is lower. According to this project possible contamination, the main pollution control and environmental objectives of the project is affirmed (see for example Table 1):

1) All production wastewater and sewage are treated effectively, after treatment all the back to achieve zero discharge of wastewater which does not adversely affect the environment of the surface water area.

2) Noise sources effect of the project is controlled which don't aggravate effect on the station community and the surrounding acoustic environment sensitive points and do not interfere with the living environment.

Table 1. The main environmental protect objects

\begin{tabular}{lrccc}
\hline & protect objects & orientation and distance from the nearest station & function \\
\hline surface water & T River & station north & Surface water of class II \\
acoustic & $\mathrm{Z} \quad$ village $\quad \mathrm{W}$ & country(A & outside the boundary south station $(0.3 \mathrm{~km}$ northwest of & Class2mixed zone 2 \\
environment & village $)$ & station site) & \\
\hline
\end{tabular}




\section{Analysis Points of the Environmental Impact Assessment}

\subsection{The Environmental Quality}

1) An overview of environmental air quality

According to pollution characteristics and the surrounding villages and other environmentally sensitive major distribution points, four monitoring sites are laid to monitor two major pollutants of TSP, PM10.The Monitoring time is spring of 2011, daily monitoring $18 \mathrm{~h}$, and the evaluation criteria is the environmental air quality standard.

2) An overview of the regional surface water environment

$\mathrm{X}$ Corporation carried out chemical and biological treatment for the waste water and sewage to reuse without more than rows. The added wastewater and domestic sewage of the technical renovation project will be treated by the existing sewage treatment plant and reuse, and wastewater is not discharged. The environmental impact assessment in phase II will lay three monitoring sections to monitor water quality in the river basin.

3) An overview of sound environmental quality

The Provincial Environmental Monitored Center in late April 2011 monitored station community noise, laid 18 noise monitoring points, evaluation through GB12348-90 "Standard of boundary noise of industrial enterprises" in the Class III area (industrial zone) standard. 18 monitoring points for the 12 daytime standards, compliance rate was $66.7 \%$; night standard number of 11 , compliance rate was $61.1 \%$. The exceeding standard point is located in the north and the south of the station, mainly due to high noise sources from clinker production line, and the distance to the north and south of the station from the boundary lines are closer. Therefore, it is necessary for some noise sources such as fans to take closures to control. In the south and north of the station wall boundary will be constructed and green belts will be planted to ensure station community noise standards.

\subsection{The Environmental Assessment Applicable Standards}

1) Environmental assessment standards

Including: Atmospheric environment, Surface water environment, Noise

Atmospheric environment: The areas belong to towns, and its function is as second-class area air environment. The evaluation criteria are used two level standards in the GB3095-1996 "Environmental Air Quality Standard".

Surface water environment: According to DB22/388-2004 "V Province Functional Areas of Surface Water", T River as Class III waters, the evaluation criteria are used Class III standards in the GB3838-2002 "Surface Water Quality Standards".

Noise: The standards of the residential areas outside the station boundary environmental noise perform Class 2 area (residential, commercial, industrial mixing zone) standards, GB3096-93 "Urban Regional Environmental Noise".

2) Pollutants emission standards

Including: Exhaust, Waste water, Noise

Exhaust: There are no process emissions and no coal-fired flue gas pollution in the project.

Waste water: water bodies due to surface water of the R River Class III waters, according to relevant standards in the GB8978-1996 “Integrated Wastewater Discharge Standard", if wastewater and domestic sewage are discharged, it should perform an emission standard of Class II.

Noise: The project region is industrial zone of the $\mathrm{P}$ town, there is no residential areas in the $100 \mathrm{~m}$ of station boundary, so the noise at boundary of the implemented Class III area (industrial zone) standard GB12348-90 "boundary of industrial enterprises noise standards".

3) The total control index

The Q Municipal Environmental Protection Bureau approved station pollutants emissions of the comprehensive utilization project of coal gangue that $\mathrm{SO} 2$ is $129 \mathrm{t} / \mathrm{a}, \mathrm{COD}$ is zero. The technology projects do not discharge $\mathrm{SO} 2$, currently the wastewater and sewage of the corporation produces are treated and reused without emissions which conforms to the total effluent control requirements; the new wastewater in the technology projects (mainly cooling water) is brought into the existing sewage treatment plant to treat, all back for cement clinker production lines, wastewater discharges COD emissions to zero, so the technology projects accord with controllable requirements of the national and local pollutant emission. 


\subsection{Major Pollutants Production and Expected to Generate Emissions}

The technical transformation project in the existing plant area is carried to transform the original power station which will replace the operation mode of the power station of the waste heat with the afterburning with operating mode of the pure low temperature waste heat power station. The construction of the main project is installation that does not destroy the green space and the environment. After the renovation project is completed, corporation can further reduce $\mathrm{SO}$, soot emissions which will help improve the ecological environment around the corporation. (see for example Table 2):

Table 2. The main pollutants related to the project and expected emissions

\begin{tabular}{|c|c|c|c|c|}
\hline & emission source & pollutants & $\begin{array}{ll}\text { concentration } & \text { before } \\
\text { treatment and output } & \end{array}$ & $\begin{array}{l}\text { expected emission } \\
\text { concentration and discharge } \\
\text { amount }\end{array}$ \\
\hline $\begin{array}{l}\text { Atmospheric } \\
\text { pollution }\end{array}$ & $\begin{array}{l}\text { without increasing } \\
\text { emissions sources }\end{array}$ & - & - & - \\
\hline Water pollution & $\begin{array}{l}\text { Factory effluent } \\
\text { (domestic sewage) }\end{array}$ & $\begin{array}{l}\text { CODSS(COD } \\
\text { SS NH3-N) }\end{array}$ & $\begin{array}{l}25 \mathrm{mg} / \mathrm{L} ; 2.46 \mathrm{t} / \mathrm{a} \\
30 \mathrm{mg} / \mathrm{L} 2.95 \mathrm{t} / \mathrm{a}(250 \mathrm{mg} / \mathrm{L} ; \\
0.038 \mathrm{t} / \mathrm{a} 180 \mathrm{mg} / \mathrm{L} ; \\
0.027 \mathrm{t} / \mathrm{a} 25 \mathrm{mg} / \mathrm{L} ; 0.004 \mathrm{t} / \mathrm{a})\end{array}$ & $\begin{array}{l}\text { Use after filtration without } \\
\text { emissions (after treatment by } \\
\text { a sewage treatment station } \\
\text { and reuse no emission) }\end{array}$ \\
\hline Solid waste & $\begin{array}{l}\text { waste heat boiler } \\
\text { Workers living }\end{array}$ & $\begin{array}{l}\text { furnace dust } \\
\text { home scrap }\end{array}$ & $3.3 \mathrm{t} / \mathrm{h} 4 \mathrm{~kg} / \mathrm{d}$ & all use without emissions \\
\hline Noise & $\begin{array}{l}\text { New water pump, steam } \\
\text { turbine and other }\end{array}$ & $\begin{array}{l}\text { The equivalent } \\
\text { noise grade in } \\
\text { succession }\end{array}$ & $80-90 \mathrm{~dB}(\mathrm{~A})$ & $\begin{array}{l}\text { Pollution that does not } \\
\text { increase plant community } \\
\text { and surrounding living } \\
\text { environment }\end{array}$ \\
\hline
\end{tabular}

2.4 Prevention and Control Measures to Be Taken on the Project and the Expected Treatment Effect (See for Example Table 3)

Table 3. Plan to apply prevention measures and the expected treatment effect

\begin{tabular}{|c|c|c|c|c|}
\hline & emission source & pollutants mane & prevention measures & anticipated treatment effect \\
\hline $\begin{array}{l}\text { Atmospheric } \\
\text { pollution }\end{array}$ & No increasing & - & - & - \\
\hline $\begin{array}{l}\text { Water } \\
\text { pollution }\end{array}$ & $\begin{array}{l}\text { Factory effluent } \\
\text { (domestic } \\
\text { sewage) }\end{array}$ & $\begin{array}{l}\text { CODSS (COD } \\
\text { SS NH3-N) }\end{array}$ & $\begin{array}{l}\text { Cleaner water quality, filtration through } \\
\text { the filter (processing in the existing } \\
\text { sewage treatment plant) (process and } \\
\text { scale as mentioned above) }\end{array}$ & $\begin{array}{l}\text { back to use clinker production line } \\
\text { humidifier, without more than rows } \\
\text { (back to use clinker production line } \\
\text { humidifier, without more than rows) }\end{array}$ \\
\hline Solid waste & $\begin{array}{l}\text { waste heat } \\
\text { boiler } \\
\text { Workers living }\end{array}$ & $\begin{array}{l}\text { furnace dust } \\
\text { home scrap }\end{array}$ & Back clinker production to produce & $\begin{array}{l}\text { No discharge, no effect on the } \\
\text { environment }\end{array}$ \\
\hline Noise & $\begin{array}{l}\text { New } \\
\text { pump, } \\
\text { turbine } \\
\\
\\
\text { other }\end{array}$ & $\begin{array}{l}\text { The equivalent } \\
\text { noise grade in } \\
\text { succession }\end{array}$ & $\begin{array}{l}\text { Apply the measures of reduction } \\
\text { vibration ,cutting off sound, absorption } \\
\text { sound and construction independent } \\
\text { pumper }\end{array}$ & $\begin{array}{l}\text { No increasing noise pollution of the } \\
\text { plant boundary and surrounding } \\
\text { living environment }\end{array}$ \\
\hline
\end{tabular}




\subsection{Environmental Investment Analysis}

This project belongs to energy project that makes use of waste heat of cement clinker production line for power generation. After completion the project resources can greatly be saved, coal consumption can be reduced, thereby reducing environmental pollution, which project itself can be seen as an environmental engineering. But as the environmental protection engineering which owns environmental pollution production needs to carry out some measures. The project needs to invest 300 million in environmental protection including noise control costs, representing the proportion of total project investment of $1.3 \%$.

In summary, the project production technology is advanced, the use of low temperature waste heat power generation, energy saving, meeting our current principles of clean production and circular economy concept.

\section{The analysis about Environment Feasibility and Comprehensive Benefits of the Project}

\subsection{The Industrial Background Analysis about the Project}

In the light of the overall industrial backwardness of China's cement industry and blind investment background, in recent years, the National Development and Reform Commission issued a series of industrial policies of the relevant continuous documents and carried out strict guidelines and limitations for departments of China's cement industry construction and production: the Development and Reform Commission to run [2006] No. 609 "issued a number of opinions to speed up the restructuring of the cement industry", "which released No.50Decree October in 2006", "Cement Industry Development Policy" for the Cement Industry Development Policy, "Industry restructuring direction catalogue" (2005), "China's saving Energy Technology Policy -2005 Amendment", and so on. The state encourages the comprehensive utilization resources identified management practices (2006) to encourage pure low-temperature waste heat power generation in large-scale dry-process cement kilns. Therefore, the construction project in line with the cement industry policy is pre-primary and conditions to determine the environmental feasibility.

The project is designed to take full advantage of $\mathrm{X}$ corporation existing $2 \times 4000 \mathrm{t} / \mathrm{d}$ clinker production line for pure low temperature waste heat power generation, transformation the existing power plant waste heat, new installed capacity $6.5 \mathrm{MW}$, designed generating capacity 51.48 million $\mathrm{kWh}$ throughout the year, so electricity supply to the cement plant can be $47,876,000 \mathrm{kWh}$. As is seen, the project is an important project encouraged and supported by national. In summary the project construction is in line with cement industry policy.

\subsection{Advanced Analysis of Clean Production}

Clean production is continually taken to improve the design, to make use of clean energy, raw materials, advanced technology and equipment, to improve management; other measures are used to reduce pollution from source to improve resource utilization efficiency, to reduce or avoid production and emission of pollutants during the production; services and products are provided in order to reduce or eliminate harm on human health and the environment. Clean production is required to implement pollution prevention principles. The pollution prevention of cleaner production is a source-controlling environmental strategy.

Pure low temperature waste heat power generation is a real sense of the waste heat power station, because it does not use fuel to make fuel, and it will not generate additional pollution to the environment. The absence of staged combustion boilers, steam parameters is lower, and its operation is simple, reliability and safe. But the pure low temperature waste heat power station must be carefully designed.

In short, the project production technology is advanced, the use of low temperature waste heat power generation, energy saving, which are in line with our current principles of clean production and circular economy concept.

\section{Conclusion}

All in all, the project conforms to national industry policy and national environmental policy. And technical transformation projects generate electricity by using the head and end of the kiln, so that the energy-saving and emission reduction are in line with the principles of clean production and recycling of China's economic strategy. The project area is carried out the expansion of waste heat power station plant construction in the existing plant without occupying new land. The project construction can make full use of waste heat and provide electricity 47.876 million $\mathrm{kWh}$ for corporation to create greater economic efficiency and reduce product costs, while reducing power plants coal-fired, saving resources, but also to reduce pollutant emissions. Pure low temperature waste heat power generation project is light pollution, and the project has little effect on the surrounding natural, ecological and living environment. The beneficial result of the project is obvious. From the environmental point of view, the project is feasible. 


\section{References}

Denise, Y., \& Deng, H. H. (2006). Urbanisation, Agriculture and Industrialisation in China. Urban Studies, 35(9), 1439-1445.

Hao, D. J. (2010, August). Cleaner production assessment points and methods in environmental impact analysis. Northern environment.

Moron, B., Calvo-Flores, D., Ramos, M., \& Almohano, M. (2009). AIEIA: Software for fuzzy environmental impact assessment. Expert Systems with Applications, 1-15.

Tapia, B., Ezcurra, E., \& Garcia, O. (2008). Appraisal of environmental impacts and mitigation measures through mathematical matrices. Environmental Management, 53(8), 25-32.

Wang, X. H. (2006). Restricting factors of development of SEA in China. Ecological Economy, 2, 55-61.

\section{Note}

Note 1. 2002 People's Republic of Environmental Impact Assessment Law.

\section{Copyrights}

Copyright for this article is retained by the author(s), with first publication rights granted to the journal.

This is an open-access article distributed under the terms and conditions of the Creative Commons Attribution license (http://creativecommons.org/licenses/by/3.0/). 